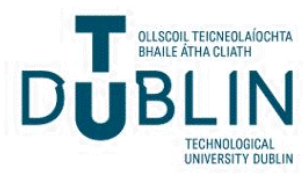

Technological University Dublin ARROW@TU Dublin

\section{Enzymes in Synthesis of Novel Functional Food Ingredients}

Amit Jaiswal

Technological University Dublin, amit.jaiswal@tudublin.ie

Samriti Sharma

Newcastle University

Follow this and additional works at: https://arrow.tudublin.ie/schfsehbk

Part of the Food Science Commons

\section{Recommended Citation}

Jaiswal, A. K., \& Sharma, S. (2015). Enzymes in Synthesis of Novel Functional Food Ingredients. In Enzymes in Food and Beverage Processing, (pp. 397- 416). CRC Press. isbn:9781138894174 doi:10.1201/ b19408-20

This Book Chapter is brought to you for free and open access by the School of Food Science and Environmental Health at ARROW@TU Dublin. It has been accepted for inclusion in Books/Book Chapters/ Proceedings by an authorized administrator of ARROW@TU Dublin. For more information, please contact arrow.admin@tudublin.ie, aisling.coyne@tudublin.ie, gerard.connolly@tudublin.ie.

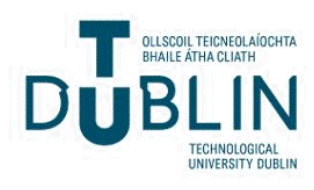


Enzymes in Synthesis of Novel

Functional Food Ingredients

\author{
Amit Kumar Jaiswal and Samriti Sharma
}

\title{
CONTENTS
}

16.1 Introduction

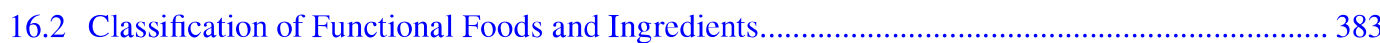

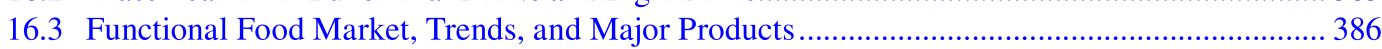

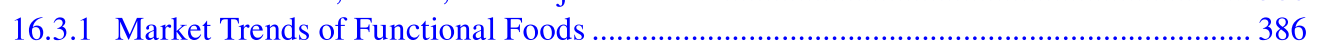

16.3.2 Industries Involved in Functional Food Production ....................................................... 387

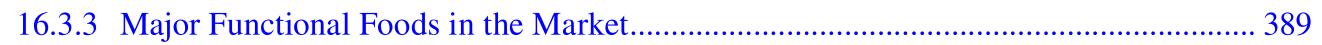

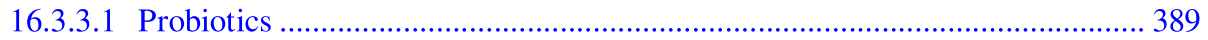

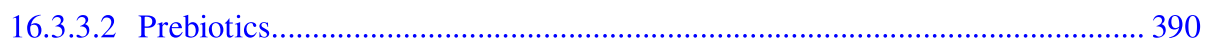

16.3.3.3 Functional Drinks ..................................................................................... 390

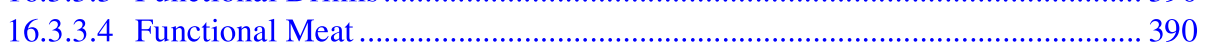

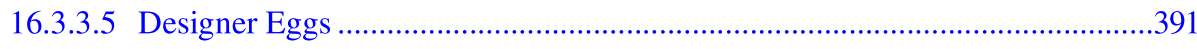

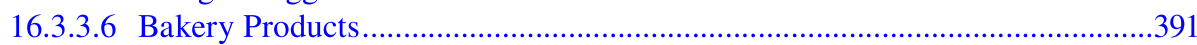

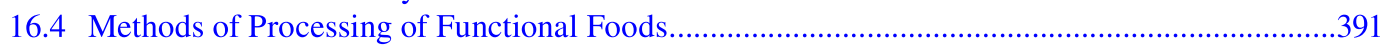

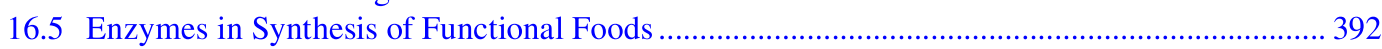

16.6 Application of Enzymes in Food Industry: Case Studies .................................................... 393

16.6.1 Enzyme-Mediated Synthesis of Nondigestible Oligosaccharides................................. 393

16.6.2 Role of Enzymes in the Synthesis of Functional Meat ................................................ 394

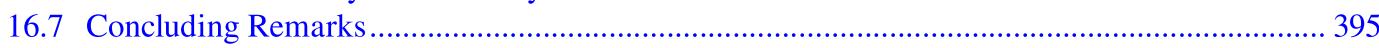

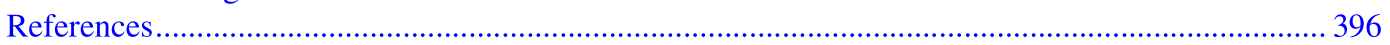

\subsection{Introduction}

The philosophy "Let food be thy medicine and medicine be thy food" was embraced by Hippocrates, the father of medicine, about 2500 years ago. This meant that the food should contain nutrition in amounts capable of meeting the energy and nutritional requirements of an individual that would ultimately help develop a strong resistance to most common infections that were then prevalent (Hasler 1998). However, with the advent of modern drug therapy, there has been a drastic change in this philosophy. This is mainly due to the decreased realization of food in health care (Hasler 2000; Milner 1999). It was also an era in which much emphasis was given to preferences and tastes over nutrition as such foods were supposed to be a major contributor to the economic growth of a country (Hasler 1998). It was in the first half of the twentieth century that increased incidences of diseases related to over-nutrition made the health care sector realize the negative impact of prolonged consumption of such foods. This led to an increased wave of awareness in the form of public health guidelines, emphasizing the importance of a balanced nutritious diet. This included a diet low in salt and saturated fats and high in vegetables, fruits, whole grains, and legumes, which help reduce the risks of chronic diseases such as cancer, diabetes, etc. This need led to the birth of "functional foods." 
Functional foods stand as a new category of remarkably promising foods that possess the properties of low cholesterol, antioxidants, anticancer, antiaging, etc. These properties render functional foods quite appealing, and subsequently, there has been increased demand for these products (Diplock et al. 1998; Mohamed 2014). Functional foods are currently a favorite topic among researchers, dieticians, and producers and consumers of the foods. To date, a wide range of definitions of functional foods exists across the world. For instance, according to Diplock et al. (1999), functional foods are those foods that can be accepted by the human body in normal amounts as part of our daily dietary needs and not as any medication. In general terms, any food that provides energy and meets the nutritional requirement of an individual on a daily basis is a functional food. Table 16.1 summarizes some of the most commonly used definitions of functional foods. Based on these definitions, it can be concluded that any food can be considered a functional food if it (a) provides health benefits, (b) constitutes a part of the normal diet, and (c) possesses nutritional functions.

In today's era, food is not only intended to satisfy hunger and provide necessary nutrients essential for the well-being of a human body, but it also plays a crucial role in the prevention of nutrition-related diseases and improves the physical and mental state of its consumers (Siro et al. 2008). Generally, functional foods are often confused with nutraceuticals; both are intended to promote health through the use of food and its components, but they are totally different terms.

"Nutraceuticals," as the name suggests, are a combination of two well-known terms: "nutrients" and "pharmaceuticals." Functional foods, on the other hand, are normal food products with certain specific functions aimed at the well-being of an individual. The two terms also differ in their modes of consumption as the former is dose dependent whereas the latter is a part of the regular diet. However, the two terms have always been a topic of debate as they can be used interchangeably at times. According to El Sohaimy (2012), functional foods for one could serve as nutraceuticals for another. This means that, when food is consumed to provide the required amounts of proteins, vitamins, and minerals to the body

TABLE 16.1

Most Commonly Used Definitions of Functional Foods

\begin{tabular}{|c|c|}
\hline Author/Organizations & Definitions \\
\hline $\begin{array}{l}\text { Food Safety Authority Ireland (FSAI), } \\
\text { Ireland }\end{array}$ & $\begin{array}{l}\text { "Functional food is a food with characteristics that can help achieve or } \\
\text { maintain good health in addition to providing basic nutrition." }\end{array}$ \\
\hline British Nutrition Foundation (BNF), UK & $\begin{array}{l}\text { "Functional food is a food that delivers additional or enhanced benefits over } \\
\text { and above their basic nutritional value and includes broad range of } \\
\text { products." }\end{array}$ \\
\hline $\begin{array}{l}\text { European Food Information Council } \\
\text { (EUFIC) }\end{array}$ & $\begin{array}{l}\text { "Functional food is a food intended to be consumed as a part of normal diet } \\
\text { and contain biologically active components which offer potential of } \\
\text { enhanced health or reduced risk of disease." }\end{array}$ \\
\hline $\begin{array}{l}\text { The Commonwealth Scientific and } \\
\text { Industrial Research Organisation } \\
\text { (CSIRO), Australia }\end{array}$ & $\begin{array}{l}\text { "Any food or food component that may provide demonstrated physiological } \\
\text { benefits or reduce the risk of chronic diseases above and beyond basic } \\
\text { nutritional functional, is a functional food." }\end{array}$ \\
\hline Agriculture and Agri-Food Canada & $\begin{array}{l}\text { "Functional foods are foods enhanced with bioactive ingredients and which } \\
\text { have demonstrated health benefits." }\end{array}$ \\
\hline $\begin{array}{l}\text { Food and Nutrition Board (FNB) of } \\
\text { National Academy of Sciences, USA }\end{array}$ & $\begin{array}{l}\text { "Functional foods are those that encompasses potentially healthful products } \\
\text { including any modified food or food ingredient that may provide a health } \\
\text { benefit beyond that of traditional nutrients that it contains." }\end{array}$ \\
\hline $\begin{array}{l}\text { Food for Specified Health Uses } \\
\text { (FOSHU), Japan }\end{array}$ & $\begin{array}{l}\text { "Foods which are based on knowledge between food and food components } \\
\text { and health expected to have certain health benefits, and have been licensed } \\
\text { to bear a label claiming that a person using them for specified health use } \\
\text { may expect to obtain the health use through the consumption thereof." }\end{array}$ \\
\hline Iowa State University, USA & "Foods that have been linked to health benefits." \\
\hline $\begin{array}{l}\text { International Food Information Council } \\
\text { (IFIC), Washington, USA }\end{array}$ & "Foods that may provide health benefit beyond basic nutrition." \\
\hline Health Canada, Ontario, Canada & $\begin{array}{l}\text { "Functional foods as products that resemble traditional foods but possess } \\
\text { demonstrated physiological benefits." }\end{array}$ \\
\hline
\end{tabular}


for its healthy survival, it is said to be a functional food. However, when this functional food is used to prevent or treat a disease or disorder, it is said to be a nutraceutical (El Sohaimy 2012).

Because the two terms are still evolving, several gaps seem to exist. Their producers wish to provide enough information on the health claims of these products. In addition, the governmental regulating bodies also face a tough time classifying these products as they occupy a position in between regular foods and drugs. Functional foods and nutraceuticals are still not legally recognized in the United States (Hasler and Brown 2009). In the European Union, on the other hand, functional food is regulated under general food law regulation (Regulation [EC] No. 178/2002) and under Regulation (EC) No. 1924/2006, which covers claims referring to health in order to avoid any confusion among its consumers (Koch et al. 2014). However, lack of a single universally accepted guideline not only fails to draw a clear line between functional foods and nutraceuticals, but it also leaves the companies entering the health food market in confusion and complicates the import and export of similar products worldwide.

\subsection{Classification of Functional Foods and Ingredients}

In the absence of uniform legal status, "functional foods" is often considered to be a marketing term across the globe. This is mainly because of the lack of a single widely accepted definition available, which thereby fails to draw a clear boundary between what can and what cannot be considered functional foods. However, based on the definitions mentioned in Table 16.1 as accepted in different parts of the world, functional foods can be broadly categorized as the following:

- Naturally occurring foods, which are the conventional foods containing naturally occurring bioactive components

- Processed foods, which have been modified by any of the following ways: addition of a component, removal of a component, modification of components, modification of bioavailability, or foods produced by the combination of any of the above methods (Henry 2010)

Table 16.2 gives examples of the most commonly known functional foods along with the main functional ingredient and the health benefits of these foods. Most of these naturally occurring functional foods have been known to mankind for their properties and have therefore been an important part of the diet. For example, tomatoes, both in raw form and processed form are one of the most widely consumed vegetables across the world. They are known to be rich in potassium, folate, and vitamins, such as A, C, and $\mathrm{E}$. In addition, they are also one of the richest sources of lycopene. Research in the past has identified the role of lycopene in inhibition of proliferation, antiandrogen, and antigrowth factor effects, such as conditions of cancer (De Marzo et al. 2007; Wang et al. 2003). Epidemiological studies have shown that tomato polyphenols are involved in physiological properties such as anti-inflammatory, antimicrobials, antiviral effects, etc. (Navarro-González et al. 2011). Flavonols found in tomatoes are an essential component for healthy skin (Canene-Adams et al. 2005; Stewart et al. 2000).

Epidemiological studies suggest that diets rich in Brassica vegetables are associated with a lower risk of several diseases, such as atherosclerosis, stroke, cancer, diabetes, arthritis, and aging, which could be due to their richness in phenolic acids, flavonoids, isothiocyanates, and glucosinolates (Cartea and Velasco 2008; Jaiswal et al. 2011). Inflammatory and antioxidation properties found in watermelon makes it another suitable choice as a functional food for obtaining health benefits of increased arginine availability, reducing serum concentration of cardiovascular risk factors, and also helping in the dietary management of metabolic syndrome in diabetes mellitus type 2 (formerly noninsulin-dependent diabetes mellitus) and obesity (Kim et al. 2014; Wu et al. 2007).

Berries such as strawberries, cranberries, and blueberries; coconut; mushrooms; soybeans; and pomegranates have also been recognized for their functional components of proven health benefits (Basu et al. 2014; Lasekan 2014). Some of these are even under clinical trials for their role in the treatment of cancer and other diseases ( $\mathrm{Gu}$ et al. 2013). These are some of the examples of naturally occurring foods with potential health benefits and considered as functional foods. In addtion, these foods are rich in several 
TABLE 16.2

Some of the Most Commonly Available Naturally Occurring Foods with Functional Components and Potential Health Benefits

\begin{tabular}{|c|c|c|c|}
\hline Functional Foods & $\begin{array}{l}\text { Functional } \\
\text { Components }\end{array}$ & Potential Benefits & References \\
\hline Tomatoes & Lycopene & Prostate health & Cortés-Olmos et al. (2014) \\
\hline Berries & $\begin{array}{l}\text { Phenolic acids, } \\
\text { flavonoids, } \\
\text { anthocyanin }\end{array}$ & $\begin{array}{l}\text { Effective in the treatment of urinary } \\
\text { tract infection and seasonal } \\
\text { influenza }\end{array}$ & Lasekan (2014) \\
\hline Pomegranate & $\begin{array}{l}\text { Polyphenols such as } \\
\text { punicalagins, } \\
\text { punicalins, gallagic } \\
\text { acid, ellagic acid }\end{array}$ & $\begin{array}{l}\text { Effective against cardiovascular } \\
\text { disease, diabetes, prostate cancer }\end{array}$ & $\begin{array}{l}\text { Johanningsmeier and Harris } \\
\text { (2011) }\end{array}$ \\
\hline Broccoli & Glucosinolate & Prevention of cancer & Jeffery et al. (2003) \\
\hline Citrus & Flavanones & $\begin{array}{l}\text { Neutralizes free radicals, reduced } \\
\text { risk of some cancers }\end{array}$ & Gattuso et al. (2007) \\
\hline Soybeans & Isoflavones & Lowers LDL and total cholesterol & Hasler (1998) \\
\hline Fish oils & Omega 3-fatty acids & $\begin{array}{l}\text { Reduced risk of cardiovascular } \\
\text { disease }\end{array}$ & Holub and Holub (2004) \\
\hline $\begin{array}{l}\text { Wheat bran, corn } \\
\text { bran, fruit skin }\end{array}$ & Insoluble fiber & $\begin{array}{l}\text { Reduced risk of breast and colon } \\
\text { cancer, promotes healthy digestive } \\
\text { tract }\end{array}$ & $\begin{array}{l}\text { Reddy et al. (2000); } \\
\text { Vitaglione et al. (2008) }\end{array}$ \\
\hline $\begin{array}{l}\text { Carrots, sweet } \\
\text { potatoes, apricots, } \\
\text { cantaloupes, } \\
\text { peaches, dark green } \\
\text { leafy vegetables }\end{array}$ & $\beta$-carotene & $\begin{array}{l}\text { Most potent pro-vitamin A form, } \\
\text { maintains healthy eyes; vision } \\
\text { cycle, reduces the risk of cancers } \\
\text { and heart diseases }\end{array}$ & $\begin{array}{l}\text { Hasler (1998, 2002); Ishida et } \\
\text { al. (2000); Schieber et al. } \\
\text { (2001); Stacewicz- } \\
\text { Sapuntzakis et al. (2001) }\end{array}$ \\
\hline $\begin{array}{l}\text { Onions, apples, tea, } \\
\text { red lettuce }\end{array}$ & Flavonols & $\begin{array}{l}\text { Reduced risks of cardiovascular } \\
\text { diseases; prevent oxidative } \\
\text { damage to cells, lipids and DNA; } \\
\text { promote bone health, prevent } \\
\text { osteoporosis; possess anti- } \\
\text { inflammatory properties }\end{array}$ & $\begin{array}{l}\text { Liu (2003); Rice-Evans } \\
\text { (2001); Schieber et al. } \\
\text { (2001) }\end{array}$ \\
\hline $\begin{array}{l}\text { Celery, oregano, } \\
\text { parsley }\end{array}$ & Flavones & $\begin{array}{l}\text { Effective against different types of } \\
\text { cancers and osteoporosis }\end{array}$ & Shahidi (2009) \\
\hline $\begin{array}{l}\text { Flaxseed, sesame, } \\
\text { whole grain wheat } \\
\text { bread, rice, cashew } \\
\text { nuts }\end{array}$ & Lignans & $\begin{array}{l}\text { Reduces cancer of reproductive } \\
\text { organs and colon cancer, improves } \\
\text { cardiovascular health }\end{array}$ & Kamal-Eldin et al. (2011) \\
\hline $\begin{array}{l}\text { Kale, spinach, corn, } \\
\text { egg, asparagus }\end{array}$ & Leutin, Zeaxanthin & Maintenance of eye health & $\begin{array}{l}\text { Halsted (2003); Hasler } \\
\text { (2000) }\end{array}$ \\
\hline $\begin{array}{l}\text { Oat bran, oat meal, } \\
\text { oat flour, barley, rye }\end{array}$ & $\beta$-glucan & $\begin{array}{l}\text { Reduce risk of coronary heart } \\
\text { diseases }\end{array}$ & Brennan and Cleary (2005) \\
\hline $\begin{array}{l}\text { Psyllium seed husk, } \\
\text { peas, beans, apple, } \\
\text { citrus fruits }\end{array}$ & Soluble fibers & $\begin{array}{l}\text { Effective in treatment for coronary } \\
\text { heart diseases and different } \\
\text { cancers }\end{array}$ & Brennan and Cleary (2005) \\
\hline $\begin{array}{l}\text { Cauliflower, broccoli, } \\
\text { broccoli sprouts, } \\
\text { cabbage }\end{array}$ & Sulforaphane & $\begin{array}{l}\text { Enhance detoxification of certain } \\
\text { undesirable compounds }\end{array}$ & Robbins et al. (2005) \\
\hline $\begin{array}{l}\text { Fish, red meat, whole } \\
\text { grains, garlic }\end{array}$ & Selenium & $\begin{array}{l}\text { Neutralizes free radicals, supports } \\
\text { maintenance of immune and } \\
\text { prostate health }\end{array}$ & Ferrari (2007) \\
\hline $\begin{array}{l}\text { Apple, pears, citrus } \\
\text { fruits, coffee }\end{array}$ & $\begin{array}{l}\text { Caffeic acid, feluric } \\
\text { acid }\end{array}$ & $\begin{array}{l}\text { Promotes eye health and heart } \\
\text { health }\end{array}$ & $\begin{array}{l}\text { Liu (2003); Rice-Evans } \\
\text { (2001); Schieber et al. } \\
\text { (2001) }\end{array}$ \\
\hline
\end{tabular}


types of oligosaccharides and offer ingredients that could be extracted for commercial production of functional foods.

Processed foods, on the other hand, are the foods that have been modified either by the addition or removal of certain components in order to increase the potential of the food product in providing health benefits to its consumers. Table 16.3 illustrates some of the most commonly available processed functional foods in the market along with their functional ingredients, added functional components, and potential health benefits.

Based on their source of origin, functional foods can also be categorized as the following:

- Plant-derived functional foods, which include foods containing active components derived from plants

- Animal-derived functional foods, which include foods containing functional components derived from animals, such as dairy products and fish oil

Foods derived from plants provide a great source of certain ingredients that have long been known for their positive impact on the health of an individual. These fruits, vegetables, nuts, legumes, whole grains, tea, coffee, etc. contain ingredients that serve as bioactive compounds, such as polyphenolic compounds, flavonoids, plant sterols and stanols, and vitamins C, E, and carotenoids (Alissa and Ferns 2012). Certain plant secondary metabolites such as glucosinolates and capsaicinoids are other examples of bioactive compounds of which the former has been found to be associated with a reduction of carcinomas in lungs, stomach, colon, and rectum, whereas the latter is supposed to provide relief from pain by acting on the peripheral part of the sensory nervous system. Although certain studies do indicate some allergic reactions associated with some of these compounds, their potential as functional ingredients cannot be avoided (Lavecchia et al. 2013).

Animal-derived functional foods can broadly be divided into two main categories as meat and eggs and dairy products. Meat and eggs have long been a part of the major diet in several civilizations. Meat

\section{TABLE 16.3}

Some of the Most Commonly Available Processed Functional Foods Along with Their Functional Ingredients, Added Functional Components, and Potential Health Benefits

\begin{tabular}{|c|c|c|c|}
\hline Functional Foods & $\begin{array}{l}\text { Functional } \\
\text { Components }\end{array}$ & Potential Benefits & References \\
\hline $\begin{array}{l}\text { Orange juice with added } \\
\text { vitamin } D \text {, juices with } \\
\text { calcium }\end{array}$ & Vitamin D & Improved bone health & Dawson-Hughes et al. (1997) \\
\hline Yogurt with probiotics & Probiotics & $\begin{array}{l}\text { Improved gastrointestinal } \\
\text { digestion }\end{array}$ & Roberfroid (2000) \\
\hline $\begin{array}{l}\text { Bread and cereals with added } \\
\text { fiber }\end{array}$ & Fibers & $\begin{array}{l}\text { Decreases the problem of } \\
\text { constipation and reduces the } \\
\text { risk of cancers }\end{array}$ & $\begin{array}{l}\text { Charalampopoulos et al. (2002); } \\
\text { Pharmaceutiques (1995) }\end{array}$ \\
\hline $\begin{array}{l}\text { Margarine fortified with plant } \\
\text { sterols }\end{array}$ & $\begin{array}{l}\text { Plant sterols and } \\
\text { phytosterols }\end{array}$ & Reduces cholesterol & Berger et al. (2004) \\
\hline Grains with folic acid & Folic acid & $\begin{array}{l}\text { Reduce risk of heart diseases } \\
\text { and neural tube birth defects }\end{array}$ & $\begin{array}{l}\text { Alissa and Ferns (2014); } \\
\text { De Wals et al. (2007) }\end{array}$ \\
\hline Juices with added fibers & Fibers & $\begin{array}{l}\text { Reduces risks of certain } \\
\text { cancers and heart diseases, } \\
\text { cholesterol, hypertension, and } \\
\text { constipation }\end{array}$ & Brennan and Cleary (2005) \\
\hline $\begin{array}{l}\text { Beverages and salad dressings } \\
\text { with antioxidants }\end{array}$ & Antioxidants & Promote overall growth & Hasler (1998) \\
\hline Sport bars and drinks & Varies with types & Extra source of energy & \\
\hline Eggs with Omega 3 fatty acids & Omega 3 fatty acids & Reduces risk of heart diseases & Holub and Holub (2004) \\
\hline
\end{tabular}


and meat-derived products are major sources of bioactive compounds, such as iron, zinc, vitamins, and minerals. Fish oil, for instance, is one of the richest sources of long-chain fatty acids, such as DHA and EPA. In certain cases, meats and eggs have been enriched with selenium to increase the functionality of the diet due to its proven role in metabolism. The dairy industry is one of the key sectors of the food industry throughout the world. Milk and milk-derived products are the richest sources of conjugated linoleic acids that provide protection from various types of cancer (Kralik et al. 2012). Probiotic products rely greatly on the dairy industry.

In general, government agencies, such as the U.S. Food and Drug Administration (FDA), control the key decisions regarding the regulation, safety, and marketing of food products. In the case of functional foods, lack of a formal definition issued by these regulating bodies gives a freedom to the manufacturers to choose the market for such products. In such cases, functional foods are currently marketed as the following:

- Enriched foods: This category includes foods that are produced by the addition of one or more nutrients that have previously been lost during their processing.

- Fortified foods: These are foods that have been prepared by the addition of one or more nutrients that impart a specific functionality.

- Enhanced foods: These are prepared by the addition of one or more active ingredients by modification or indirect methods.

- Altered foods: These are produced by the removal, reduction, or replacement of a deleterious component by some beneficial ingredient.

Usually, functional foods are those foods that contain at least one ingredient that provides an important function in improving health and/or reducing the chances of disease, such as diabetes, cancer, hypertension, and several cardiovascular diseases (Granato et al. 2010). These ingredients may include prebiotics, probiotics, antioxidants, carotenoids, lycopene, etc. As discussed earlier, the natural functional foods include the class of conventional foods that are unmodified whole foods, such as fruits and vegetables. Processed foods, on the contrary, include foods that have been modified by any of the processes, such as fortification, enrichment, or enhancement of conventional foods. These include calcium-fortified juices, folate-enriched breads, or foods enhanced with bioactive components, such as plant sterols (Granato et al. 2010).

Efforts are also being made to modify foods using biotechnological approaches to improve the nutritional value of foods, thereby creating a new field of foods in the market. These include foods with increased omega 3-fatty acids or decreased trans-fatty acid content (Granato et al. 2010). Some of the most common products that are found in markets throughout the world include probiotics, prebiotics, functional cereals, functional meat, functional eggs, etc. Despite their development in all food markets, functional food products are not homogeneously scattered over all segments of the food industry. Some of the major products include confectionery, dairy, soft drinks, bakery, and the baby food market (Siro et al. 2008).

\subsection{Functional Food Market, Trends, and Major Products}

\subsubsection{Market Trends of Functional Foods}

Over the past few years, the concept of functional foods has gained momentum, which is on account of an increased understanding of the relationship between nutrition and health. Despite their existence in a wide range of foods, they fail to attain uniform distribution in all segments of the growing market (Siro et al. 2008). Technical obstacles, lack of proper legislation, and consumer willingness are some of the main reasons that make the development and commerce of functional foods a complex, expensive, and risky task (Siro et al. 2008). This could be because of the lack of a globally accepted definition of functional foods. This creates confusion in the minds of its consumers regarding functional food products. As a result of this, consumers prefer products such as yogurt, cereals, and juices as healthy functional foods that are well known (Annunziata and Vecchio 2011). 
Since the birth of the concept of functional foods, Japan has pioneered the development of this sector of the food industry, generating interest and awareness in the regions of the United States and Europe. These countries took no time in realizing the potential of functional foods in reducing the cost of health care and as a source of commercial revolution in the food industry. It is estimated that global functional food markets contribute US\$33 billion to the overall food industry with the United States offering the largest market segment, followed by Europe and Japan (Siro et al. 2008). Due to ambiguity about the functional food products across the globe, certain other studies estimate a much higher value of US\$61 billion to the functional food market. Despite these variations in the share of functional foods, they are supposed to contribute to $90 \%$ of the sales from the three main markets of the United States, Europe, and Japan (Siro et al. 2008).

Countries such as Germany, France, the Netherlands, and the United Kingdom constitute the major functional food markets of Europe with Hungary, Poland, and Russia being some new emerging ones since 2005 (Annunziata and Vecchio 2011). However, a high level of divergence exists between the Eastern and Western countries of the world with respect to the nature of functional foods. In the Eastern world, for instance, Foods for Specific Health Use (FOSHU) labeled functional foods are accepted as first-generation functional foods and preferred for their function over taste. On the contrary, emphasis is laid on adding functionality to traditional foods rather than considering them as a separate class (Siro et al. 2008). Not only this, but variation also exists within different states of Europe based on food traditions and cultural heritage with higher numbers of consumers in the northern and central parts as compared to the Mediterranean regions (Annunziata and Vecchio 2011).

Despite the efforts by the food industries throughout the globe, functional foods still suffer great losses. This was mainly because most companies developed a single product rather than throwing a range of products into the market, thereby providing the customers with fewer options to choose from (Menrad 2003).

\subsubsection{Industries Involved in Functional Food Production}

The market for functional foods is very unevenly distributed across the world. Certain types of functional foods are much more favored among consumers. This is mainly influenced by their use in certain cultures that dates back several centuries. However, increased cost of health care and awareness among consumers regarding the state of well-being and a healthy lifestyle are playing major roles in the growth of the present functional foods market. Functional products are mainly launched in dairy, beverages, bakery, confectionery, and the baby food market. The European market currently is flooded by products promising gut health, specifically probiotic-based products. Menrad (2003) divided key suppliers of functional food products into the following categories:

- Multinational food companies

- Pharmaceutical companies and companies involved in the production of dietary supplements

- National category leaders

- Small and medium-sized companies

- Retail companies

- Suppliers of functional ingredients

Major multinational companies involved in the production of functional foods are Yakult Honsa Co. Ltd., Danone, Unilever, Nestle, Kellogg, and Quaker Oats. Table 16.4 demonstrates major functional foods and the industries involved worldwide. Yakult Honsa Co. Ltd., established in 1930, is a Japanbased company that introduced the concept of probiotic-based dairy products for the first time. Its first product was Yakult, which was brought to the market in 1935 and is a fermented mixture of skim milk with a specific strain of Lactobacillus casei Shirota. Following its success in the Japanese market, the product is now marketed in 31 different countries, such as Australia, New Zealand, India, Indonesia, Vietnam, America, the Philippines, Thailand, South Korea, Singapore, Hong Kong, and China. Mexico serves as one the largest Yakult selling markets. 
TABLE 16.4

Major Functional Food Brands Worldwide

\begin{tabular}{|c|c|c|}
\hline Functional Foods & Products & Companies \\
\hline \multirow[t]{4}{*}{ Dairy products } & Probiotic yogurt/drinks & $\begin{array}{l}\text { Dannon (France) } \\
\text { CoolBrands International (Canada) } \\
\text { Yakult (Japan) } \\
\text { National Foods (Pakistan) }\end{array}$ \\
\hline & Cholesterol lowering yogurt & Dannon (France) \\
\hline & Omega 3 yogurt and milk & $\begin{array}{l}\text { Jalna Dairy Foods (Australia) } \\
\text { PB Foods (UK) }\end{array}$ \\
\hline & Fortified milk & $\begin{array}{l}\text { Borden (USA) } \\
\text { PB Foods (UK) } \\
\text { Murray Goulbum (Australia) }\end{array}$ \\
\hline \multirow[t]{4}{*}{ Bakery products } & Whole grain and fortified breads & $\begin{array}{l}\text { Sara Lee (USA) } \\
\text { George Weston (Australia) }\end{array}$ \\
\hline & Breads with omega 3 fatty acids & $\begin{array}{l}\text { Wegmans Food Markets (USA) } \\
\text { Arnold Foods (USA) } \\
\text { George Weston (Australia) }\end{array}$ \\
\hline & High-fiber cookies & $\begin{array}{l}\text { RD Foods (USA) } \\
\text { Quaker (UK) }\end{array}$ \\
\hline & High-fiber white bread & $\begin{array}{l}\text { Quality Bakers (Australia) } \\
\text { George Weston }\end{array}$ \\
\hline \multirow[t]{10}{*}{ Cereal products } & Heart-healthy cereals & $\begin{array}{l}\text { Quaker (UK) } \\
\text { Kraft Foods (USA) } \\
\text { Kellogg (USA) } \\
\text { Uncle Toby's (Australia) }\end{array}$ \\
\hline & Calcium-fortified cereal bars & $\begin{array}{l}\text { Quaker (UK) } \\
\text { Kellogg (USA) }\end{array}$ \\
\hline & High-fiber cereal bars & Kellogg (USA) \\
\hline & Heart-healthy cereal bars & Nature Valley \\
\hline & Whole grain pasta & $\begin{array}{l}\text { Barilla (Italy) } \\
\text { Kraft (USA) }\end{array}$ \\
\hline & Ready-to-eat energy treats & Kellogg (USA) \\
\hline & Ready-to-eat health bars & Kellogg (USA) \\
\hline & Ready-to-eat biscuits & Sanitarium \\
\hline & Ready-to-eat staples & Kellogg (USA) \\
\hline & Ready-to-eat bran & Kellogg (USA) \\
\hline Soy & Soy milk & $\begin{array}{l}\text { White Wave (USA) } \\
\text { Sanitarium (Australia) } \\
\text { Parmalat (Italy) }\end{array}$ \\
\hline \multirow[t]{3}{*}{ Beverages } & Fruit juices and juice blends & $\begin{array}{l}\text { Tropicana (USA) } \\
\text { Minute Maid (USA) } \\
\text { Ocean Spray (USA) } \\
\text { National Foods (Pakistan) } \\
\text { Campbell Soup (USA) }\end{array}$ \\
\hline & Enhanced waters & $\begin{array}{l}\text { Gatorade (USA) } \\
\text { Energy Brands (USA) } \\
\text { PepsiCo (USA) } \\
\text { Coca-Cola (USA) }\end{array}$ \\
\hline & Teas with antioxidants & $\begin{array}{l}\text { Tetley (UK) } \\
\text { Lipton (UK) }\end{array}$ \\
\hline
\end{tabular}


TABLE 16.4 (CONTINUED)

\begin{tabular}{lll}
$\begin{array}{l}\text { Major Functional Food Brands Worldwide } \\
\text { Functional Foods }\end{array}$ & \multicolumn{1}{c}{ Products } & \multicolumn{1}{c}{ Companies } \\
\hline Meat, fish, eggs & Canned fish with omega 3 & $\begin{array}{l}\text { Star-Kist (USA) } \\
\text { Chicken of the Sea (USA) }\end{array}$ \\
& & Heinz (USA) \\
& Fish oil supplements & Bumble Bee and Leiner Health (USA) \\
& Frozen fish with omega 3 & Simplot (Australia) \\
& Omega 3-DHA/lutein enriched & Gold Circle Farms (USA) \\
& eggs & Eggland's Best (USA) \\
& & Pace Farms (Australia) \\
& Farm Pride (Australia) \\
\hline
\end{tabular}

Danone is another leading name in the field of probiotic products. This French company deals with a wide range of dairy products, cereals, baby foods, and yogurts sold under brand names such as Actimel, Activia, YoCrunch, and Dannon (the United States). This French-based multinational company has several joint ventures with companies such as Britannica (India), Yakult (Japan), Bright Dairy (China), etc. Another well-known brand available in the market is Becel ProActiv, which is a margarine-based UniLever product claiming to reduce cholesterol levels. The brand is sold in countries such as Belgium, Brazil, Bulgaria, Canada, Estonia, Denmark, Finland, Germany, Greece, the Netherlands, Portugal, Romania, the United Kingdom, Ireland, Spain, Poland, Australia, New Zealand, and South Africa, where it is sold under the name Flora.

Novartis, GlaxoSmithKline, Johnson \& Johnson, and Abbott Laboratories are some of the renowned pharmaceutical companies also involved in the production of a range of functional food. Novartis launched a project named AVIVA to market a line of functional food products in 1999 in Austria and Switzerland, which was later withdrawn in the year 2001 owing to lesser consumer willingness to pay more for such foods. The Altus Food Company was another joint venture of Novartis and Quaker Oats to target the functional food market in the United States, Canada, and Mexico. GlaxoSmithKline contributes to the functional food market through its products such as Ribena, which is a fruit-based soft drink available in both carbonated and noncarbonated forms claiming to be fortified with vitamins such as A and E; and Lucozade, which is a series of energy and soft drinks. Retail stores such as ALDI and LIDL have come up with their own label brands, especially in the dairy sector, in recent years across Europe.

However, it has been seen that multinational companies lead the sales of functional food products, which could be attributed to their well-established R\&D departments and specific in-house resources and expertise in the domain of functional food technology and research (Menrad 2003). Also the history of success of these companies helps develop a positive image among consumers, which aids in the product development and marketing required for these functional food products. Small- and medium-scale companies, on the other hand, lack the adequate know-how, intensive $\mathrm{R} \& \mathrm{D}$, and investment required for the launch of such products (Menrad 2003).

\subsubsection{Major Functional Foods in the Market}

\subsubsection{Probiotics}

According to the FDA, probiotics are defined as "live microorganisms that, when administered, confer a health benefit on the host." The most commonly used microorganisms are Lactobacillus and Bifidobacterium, which have been proven to exist in the human intestinal tract (Siro et al. 2008). Probiotics with these and several other bacteria have long been found to provide a healthy gut. Probiotics help enhance nutrient availability, reduce lactose intolerance, prevent and treat allergies and eczema, and treat irritable bowel syndrome, infections caused by Helicobacter pyroli (Drago et al. 2013; Godin 1998). With a view to fulfill the proposed health claims, a wide range of products serves as carriers of probiotic strains. These include dairy-based products, such as sweet drinks, flavored milk, cheeses, and yogurt; 
soy-based products, such as soy milk and soy cream cheese; and juice-based products, such as tomato juice, carrot juice, orange juice, etc. (Nagpal et al. 2012). These products are marketed under different trade names throughout the world.

Due to their years-long use in several cultures and a positive image among consumers, probiotics hold a major share of the functional food market. Among the probiotic markets, Europe represents the largest and fastest-growing market, followed by Japan (Yamaguishi et al. 2011). It accounts for a share of $>1.4$ billion euros with the biggest sales of 1 billion euros achieved by yogurts and desserts, followed by probiotic milk (Saxelin 2008). Current market leaders for probiotic-based functional foods include Danone, Yakult, Nestle, etc. The probiotic market generated US\$15.9 billion in 2008 and was projected to reach US\$28.8 billion by 2015 (Yamaguishi et al. 2011).

\subsubsection{Prebiotics}

Prebiotics were first introduced by Gibson and Roberfroid (1995). Prebiotic means "a non-digestible food ingredient that beneficially affects the host by selectively stimulating the growth of one or a limited number of bacteria in the colon." These food ingredients include inulin, fructo-oligosaccharides (FOS), transgalactosylated oligosaccharides, and soybean oligosaccharides that, for instance, promote the growth of bacteria such as bifidobacterium and lactobacilli (Manning and Gibson 2004; Schrezenmeir and de Vrese 2001). Other similar prebiotic food ingredients include glycooligosaccharides, glucooligosaccharides, lactulose, lactitol, maltooligosaccharides, xylooligosaccharides, stachyose, raffinose, and sucrose thermal oligosaccharides (Patterson and Burkholder 2003). Improved flora inside the gut thus results in increased resistance to pathogenic bacteria, lower levels of blood ammonia, increased immune response activation, and a reduced risk of cancer (Manning and Gibson 2004). One of the most widely used prebiotics is inulin-type fructans. Inulins are "polydisperse carbohydrate material consisting mainly of $\beta$ (2-1) fructosyl-fructose links."

Prebiotic products have been classified on two main criteria: (i) their resistance to gastric juices, hydrolysis by the enzymes, and absorption by the gastrointestinal tract and (ii) their fermentation by microorganisms present in the intestine and selective stimulation of the growth of intestinal microflora associated with health and well-being (Roberfroid 2007). Current prebiotic sales are US\$110 million, which is expected to double in the next 5 years. Thirty-five percent of this market is contributed by inulin-based products, $25 \%$ by mannan oligosaccharides, and $10 \%$ by fructan oligosaccharides.

\subsubsection{Functional Drinks}

Functional drinks are another subsector of functional foods currently known in the market. It includes nonalcoholic beverages that are fortified/enhanced to provide health benefits of improved heart health, immunity, digestion, bone health, etc. Some of the common products in this category include functional drinks with herbal extracts, high-efficiency sport drinks, cholesterol-lowering drinks, eye-health drinks, bone-health drinks, and ready-to-drink teas (Whitehead 2008). Studies have shown that fruit drinks containing $\beta$-glucan can reduce serum concentrations of LDL cholesterol, and reduction in non-HDL and LDL cholesterol was observed in the case of soy drinks enriched with plant sterols, thereby providing a solution to manage hypercholesterolemia (Weidner et al. 2008). Other types of functional drinks are ACE drinks, in which antioxidant vitamins A, C, and E are added to fruit- and vegetable-based soft drinks. In order to achieve a desirable value of vitamin A in drinks, compounds such as retinol, retinyl acetate, retinyl palmitate, and $\beta$-carotene are added to them (Viñas et al. 2013). Several fruit juices, such as orange juice, have also been fortified with sterol esters to attain potential health benefits (AlemanyCosta et al. 2012).

\subsubsection{Functional Meat}

Functional meat is another category of functional food that has been brought to the market in order to achieve increased health benefits. This has been done while keeping in mind the increasing demand of meat and expansion of the meat industry throughout the world. In developing countries, meat has always 
been seen as the food of the rich. But with increased industrialization, more and more countries are entering the list of developed countries. It is also reported that the consumption of meat in developing countries has increased over the past decades. Thus, it provides an opportunity to follow practices that can improve the functionality of the existing products available in the market, thereby bringing a new term of functional meat to its consumers. Recent research has shed light on the presence of several meat-based bioactive ingredients, such as carnosine, anserine, L-carnitine, and conjugated linoleic acid (Arihara 2006).

The functional quality of meat and meat-based products could be improved by several means, for example, modification of carcass composition at the animal production stage and altering the meat raw materials in addition to reformulating meat products by reducing fat content; modifying fatty acid profile; reducing cholesterol, calories, sodium content, and nitrites; and incorporating functional ingredients of both plant and animal origin (Jiménez-Colmenero et al. 2001). Conventional meat products have been combined with fish or sea-related products to balance the omega-6/omega-3 polyunsaturated fatty acids (PUFAs) in the diet and obtain a synergic combination of antioxidants in order to increase the intake of antioxidants considering their role in reduction of free radicals from the body (Reglero et al. 2008) Market studies have identified Europe to be a great potential platform for meat products containing fiber (López and Pérez-Alvarez 2008).

\subsubsection{Designer Eggs}

Attempts have been made to produce designer eggs that will revolutionize the functional food market in the future. As the name suggests, these are eggs enriched with linolenic acid (a precursor of DHA) to provide protection against fatal ischemic heart disease (Brouwer et al. 2004). This is achieved by enriching the hen's diet with flaxseeds or linseeds, resulting in the enrichment of the egg yolk with alpha-linolenic acid. Another alternative is to enhance the levels of n-3 in the egg by including preformed DHA in the diet.

\subsubsection{Bakery Products}

Bakery products constitute one of the largest sectors of the food industry due to increased dependence of consumers around the world. They thus serve as a good option to introduce ingredients that can improve the functionality of the currently available bakery products. Bakery products possess wheat flour, semolina, and water as the main constituents. High starch content in these ingredients is an excellent source of energy, proteins, and fatty acids. They also contain certain essential vitamins, minerals, antioxidants, and phytochemicals. Efforts in the past have been made to enrich bread with omega 3 PUFAs to increase essential fatty acid intake. In order to produce a bakery product with additional functions, technologies such as Super Micro Atomization Retention Technology (SMART) are required to produce SuperCoat omega 3 products (Kadam and Prabhasankar 2010). Another study shows that bread can be enriched with microencapsulated tuna oil that increases DHA (Yep et al. 2002). Rice bran, which is usually either discarded or used no more than as an animal feed, is now being utilized to add functional properties to bread. This is targeted to introduce the nutraceutical properties of rice bran into bread (Lima et al. 2002).

$\beta$-Glucan is a type of soluble fiber that has gained importance in cereals as an active functional ingredient. Research has already provided facts supporting its role in insulin resistance; reducing hypertension and obesity; lowering serum cholesterol levels; and stimulating the immune system, anticoagulants, antimutagenic, and antitumorigenic properties (Mantovani et al. 2008; Wood 2007). The level of $\beta$-glucans varies from $1 \%$ in wheat grains to $5 \%-11 \%$ in barley. Considering the health benefits of $\beta$-glucans, breads and pasta have been enriched with these ingredients in order to produce another category of functional foods, known as functional cereals (Brennan and Cleary 2005). These cereals will thus serve as fermentable substrates, promoting growth of microflora inside the gut.

\subsection{Methods of Processing of Functional Foods}

In order to prepare a desired functional food product, several production steps are necessary in order to produce a food product from raw ingredients; change the physical and chemical appearance of the 
product; ensure food safety, constant quality, and shelf life; and add or remove one or another component to achieve the desired functional benefits. In general, heat treatment is the most widely used method for several solid and liquid products to make them palatable with an added bioavailability of nutrients, denaturized proteins, and modified carbohydrates and starches and to develop desired flavors, aroma, color, and texture or to inactivate microorganisms to reach required sterility. However, as a consequence of heat treatment, there are certain degrees of loss in nutritional contents of food products. Fruits and vegetables are a major source of functional ingredients, such as polyphenols, flavonoids, and isothiocyanates, etc., and are generally extracted using organic solvents, which may be toxic and are not environmentally friendly.

In recent years, several alternative strategies have been employed for the processing of functional foods, which preserve inherent properties of raw material intact as well as extract higher content of functional ingredients from plant materials as compared to conventional methods. In order to achieve this, several novel food processing methods have been developed and employed in the food industries; for example, ultrasonication uses high-frequency short pulses to disrupt the cell wall of microorganisms, thereby leading to its inactivation. Ultrasonication treatment has been reported to increase the shelf life of food products and also increase bioactive extraction (Briones-Labarca et al. 2015). High hydrostatic pressure (HHP) uses high pressure in the range of 100-600 MPa for food processing. As this is a nonthermal technology, sensory and nutritional attributes of the product remain virtually unaffected, thus yielding products with better quality than those processed using traditional methods. It has the ability to inactivate microorganisms as well as enzymes responsible for shortening the life of a product. In addition, it can modify the functional properties of components, such as proteins, which, in turn, can lead to the development of new products (Briones-Labarca et al. 2015).

Pulse electric field (PEF) processing is a nonthermal food processing technology, which uses a series of short and high-voltage pulses to pasteurize liquid food. This process renders microorganisms inactive and also acts upon enzymes, such as peroxidases and polyphenol oxidases, which cause enzymatic browning and color changes in food. It also aids in the extraction of nutraceuticals from plant parts (San Martin et al. 2002; Segovia et al. 2015). However, these processing methods have several drawbacks, such as being expensive, tedious to operate, being hazardous, having high processing costs, and requiring stringent process control operations. These problems demand a novel and optimized method for the production of functional foods. Enzyme-assisted production of functional food is an age-old concept whose extensive applications have recently come into the limelight with the advancement of biotechnology (Puri et al. 2012).

Enzymes are biological catalysts with high substrate specificity. They are highly precise in the reaction they catalyze and can perform in mild conditions in aqueous solutions. Because of their biological nature, enzymes are ideal for the extraction of new food ingredients for functional food applications and can also be applied in a range of functional food product development. The use of enzymes in the food industry also provides a cleaner and greener alternative as opposed to conventional chemical reaction processes currently employed in nutraceutical production (Meyer 2010). The ability of enzymes to cleave biomolecules at specific sites results in better yields of the desirable compounds as compared to physical and chemical processing methods.

\subsection{Enzymes in Synthesis of Functional Foods}

These days, enzymes are isolated from living cells, which led to their pilot-scale production and wider application in the food industry. Microorganisms are the most important source of commercial enzymes. Microorganisms do not contain the same enzymes as plants or animals, but usually, it is found that they produce a similar enzyme that will catalyze the desired reaction. There is much emphasis focused on the isolation and identification of novel microbial strains for the production of desired enzymes or strains derived from mutation and genetic engineering (Afifi et al. 2014; Liu et al. 2014); however, in the industry, a large number of microbial enzymes come from a very limited number of genera, and Aspergillus and Bacillus are the most predominate species.

Enzymes that are used in the food industry are supposed to conform to certain safety guidelines before they can be commercially exploited. An overall safety assessment of each enzyme preparation intended 
for use in food or food processing must be performed. This assessment should include an evaluation of the safety of the production organism, the enzyme component, side activities, the manufacturing process, and the consideration of dietary exposure (FAO 2001). All the enzymes from animal origin and preparation of enzymes must comply with meat inspection requirements and be handled in accordance with good hygienic practice, and plant-origin enzyme preparations must contain components that leave no residues harmful to health in the processed finished food under normal conditions of use (FAO 2001). However, according to safety regulations for enzymes obtained from microbial strains, the following issues were considered: the pathogenicity and toxicity of the production strain, allergies and irritations, interaction of enzymes from other food components, products of enzymatic reactions, carcinogenic and mutagenic effects, and the effect of food enzymes on consumption. The primary focus when assessing a production strain is its toxigenic potential. Toxigenic potential is defined as the ability of a microorganism to produce chemicals (toxins) that can cause food poisoning.

The fungal-origin enzymes should be evaluated for toxicity; they should not contain significant amounts of mycotoxins that are known to be synthesized by production strains. Source microorganisms must be discrete and stable strains or variants that have been taxonomically characterized to enable them to be assigned unique identities as the sources of the enzyme preparations that are the subject of individual specifications (Landry et al. 2003). The reference or production strain number may be included in individual specifications. In addition, culture media used for the growth of microbial sources must consist of components that leave no residues harmful to health in the processed finished food under normal conditions of use (FAO 2001).

A single class of enzyme can be used for different purposes. The primary question that needs to be answered is the objective that has to be achieved: Is the enzyme going to be used for reduction of viscosity; change the texture or flavor of food; or remove certain characteristics, such as bitterness, from beverage products. Enzymes may be selected based on the nature of the substrate they act upon, such as starch, protein, and fats. Another aspect that should be evaluated during enzyme selection is the overall conditions of the food or the beverage, such as $\mathrm{pH}$, temperature, moisture content, reaction time necessary, and other processing conditions. The source of the enzyme also determines its operational efficiency; for example, fungal enzymes tend to be more active in acidic $\mathrm{pH}$, and bacterial, yeast, and animal sources show higher activity in alkaline conditions. It is also necessary to study the side reactions of the enzymes as well. For example, fungal proteases used in flour production also exhibit amylase activity (Guo and $\mathrm{Xu} 2005)$.

\subsection{Application of Enzymes in Food Industry: Case Studies}

\subsubsection{Enzyme-Mediated Synthesis of Nondigestible Oligosaccharides}

According to IUPAC nomenclature, oligosaccharides are saccharides that contain 3-10 sugar moieties. These oligosaccharides are low molecular weight carbohydrates and can be classified as digestible and nondigestible based on their physiological properties. Roberfroid (1997) defined nondigestible oligosaccharides (NDOs) as "an oligomeric carbohydrate, the osidic bond of which is in a spatial configuration that makes it resistant to the hydrolytic activity of the intestinal digestive enzymes. However, it is still sensitive to hydrolysis by enzymes of the colonic bacteria which then ferment its monomers to produce short chain carboxylic acids, gases and cellular energy for metabolic activities, growth and proliferation."

Nondigestible oligosaccharides have long been known for their functional properties (Roberfroid 1997). They possess certain physiological and physicochemical properties that make them behave as dietary fibers and prebiotics (Mussatto and Mancilha 2007). A diet enriched with NDOs helps improve the microbiology of the gut by encouraging the growth of healthy microflora inside the gut. They do so by promoting the growth of certain specific microorganisms, such as Bifidobacterium and Lactobacillus over other pathogenic bacteria followed by their predominance in the gastrointestinal tract as observed through their increased occurrence in the feces (Pharmaceutiques 1995). It is believed that the configuration of the osidic bond prevents the hydrolysis of the NDOs in the upper part of the gastrointestinal tract. These later undergo the metabolic process known as fermentation in the caeco-colon, serving as an 
indirect energy substrate. It is due to this fermentation that the $\mathrm{pH}$ of the gut decreases, thereby preventing the development of bacterial strains such as E. coli, Clostridia, etc. (Delzenne and Roberfroid 1994). It also helps improve the absorption of minerals from the intestine and lipid metabolism, prevent cancer of certain types, and develop a strong immune system (Swennen et al. 2006).

Based on the type of monosaccharide unit attached, nondigestible saccharides can be glucooligosaccharides, galactooligosaccharides, fructooligosaccharides, and xylooligosaccharides (Mussatto and Mancilha 2007). In addition, other compounds known as NDOs are lactulose, isomaltulose, raffinose, cyclodextrins, and glycosylsucrose (Mussatto and Mancilha 2007). These NDOs can be obtained by several methods, such as (i) direct extraction from natural sources, (ii) chemical synthesis from disaccharides or polysaccharides, and (iii) enzymatic methods (Mussatto and Mancilha 2007). Oligosaccharides can be prepared from lactose enzymatically by (i) transgalactosylation with lactose as the galactosyl donor and $\beta$-galactosidase as the catalyst synthesizing galactooligosaccharide, (ii) transgalactosylation of fructose and sucrose with $\beta$-galactosidase as the catalyst yielding lactulose and lactosucrose, and (iii) transfructosylation or transglucosylation of lactose with sucrose as the glycosyl donor and levansucrase or dextransucrase as the calayst forming lactosucrose and glucosylactose, respectively (Gänzle 2012).

Of all the abovementioned NDOs, galactooligosaccharides (GOS) are the most commonly used and known prebiotics. GOS are composed of 2-10 galactose units linked to a terminal glucose unit by $\beta$ (1-4) and $\beta$ (1-6) bonds. Recent studies have shown that GOS poses a positive impact on immunity and calcium absorption in the body (Rastall 2013). GOS is an intermediate product of the lactose hydrolysis by a hydrolase enzyme, $\beta$-galactosidase, which attacks the o-glucosyl group of lactose (Torres et al. 2010). Thus, in processes involving the hydrolysis of lactose, GOS is often considered to be an undesirable by-product. However, considering the prebiotic properties of GOS, there has been an increased interest in the commercial production of GOS by various food and pharmaceutical sectors (Torres et al. 2010).

GOS are most commonly prepared by enzymatic methods (Gänzle 2012; Torres et al. 2010). Glycosyltransferase (EC. 2.4) and glycoside hydrolase (EC. 3.2.1) are the two enzymes used to catalyze the production of GOS (Torres et al. 2010). Glycosyltransferase does so by catalyzing the formation of glycosidic linkage through transfer of a saccharide from donor to the acceptor molecule; glycoside hydrolase, on the contrary, catalyzes the hydrolysis of a glycoside bond by two mechanisms, depending upon the stereochemistry as the (i) inverting mechanism or (ii) retaining mechanism (Davies and Henrissat 1995). However, factors such as poor availability, high prices, and choice of sugars as the substrates restrain glycosyltransferases to be used for commercial production of GOS.

Glycoside hydrolase, on the other hand, is preferred for producing GOS commercially due to its increased availability (Torres et al. 2010). As mentioned above, glycoside hydrolases are generally known for their hydrolyzing property; however, in certain cases, retaining glycoside hydrolases can be used to synthesize glycosidic linkages by the process known as transglycosylation (Van Den Broek and Voragen 2008). The glycoside hydrolase consists of GH1, GH2, GH35, and GH42 families based on the types of substrates whereas the catalytic mechanism remains the same (Gänzle 2012; Van Den Broek and Voragen 2008).

$\beta$-Galactosidase is by far the most commonly known glycoside hydrolase that catalysizes the formation of GOS from lactose. $\beta$-Galactosidase of the $\mathrm{GH} 2$ family has higher lactase hydrolysis activity and transglycosylation activity than GH42 (Van den Broek et al. 2005). However, a competition always remains between both mechanisms. In order to favor transglycosylation over hydrolysis to promote the synthesis of galactooligosaccharides, it is necessary to optimize reaction parameters, such as $\mathrm{pH}$, temperature, substrate concentration, etc. (Van Den Broek and Voragen 2008). In some cases, site-directed mutagenesis has been applied to enhance the feasibility of the reaction. Also, GH42 $\beta$-galactosidase from Lactobacilli and Bifidobacteria are inhibited by high concentrations of lactose and thus less preferred for transgalactosylation.

\subsubsection{Role of Enzymes in the Synthesis of Functional Meat}

The meat industry is one of the world's largest growing food sectors. With increasing demands for meat and meat-based products and competition, tremendous efforts and contributions have been made in the field of research to increase the quality of these products. Meat is a great source of fatty acids, minerals, 
dietary fiber, antioxidants, and bioactive peptides (Decker and Park 2010). Considering the increased demand for healthier food options, functional meat offers a great potential both for producers and consumers. For instance, muscle foods are a major source of bioactive compounds, such as iron, zinc, conjugated linoleic acids, and vitamin B (Jiménez-Colmenero et al. 2001).

Meat and meat-based products can be modified in the following ways to improve their functional properties: (i) addition of ingredients and (ii) removal of harmful compounds. One such example is the addition of olive oils to traditional Spanish sausage to replace up to $30 \%$ of the pork back fat (FernándezGinés et al. 2005; Muguerza et al. 2001). The functional value of meat can be improved by adding functional compounds, such as conjugated linolenic acid, vitamin E, n3 fatty acids, and selenium in the animal diet or ingredients such as vegetable proteins, dietary fibers, herbs, spices, and lactic acid bacteria during the processing of meat (Zhang et al. 2010). In addition, recent work also demonstrates the generation of peptides from meat and meat products during the processes of fermentation, curing and aging, and enzymatic hydrolysis (Zhang et al. 2010).

Research in the past has identified peptides released from animal and plant proteins that offer attributes of antimicrobial properties, blood pressure-lowering effects, cholesterol-lowering effects, antioxidant properties, immunomodulatory effects, etc., to a human body that is beyond normal nutrition (Hartmann and Meisel 2007). These peptides, often known as bioactive peptides, remain inactive within their parent protein and are released inside the gastrointestinal tract or during the processing of foods containing these peptides (Korhonen and Pihlanto 2003). Lafarga and Hayes (2014) described bioactive peptides as 2-30 amino acid sequences that impart a positive health effect to consumers. This section, however, focuses on meat-based bioactive compounds. Some of the examples of such compounds include conjugated linoleic acid, carnosine, anserine, L-carnitine, glutathione, taurine, creatine, etc. (Arihara 2006). Bioactive peptides can be produced (i) during processing of meat and meat-based products by methods of fermentation and enzymatic hydrolysis and (ii) directly from meat proteins, followed by their use to enrich the meat (Arihara 2006; Jang and Lee 2005; Saiga et al. 2003).

Meat has largely been used to synthesize bioactive peptides by enzymatic methods. ACE inhibitory peptides are one such group of bioactive peptides synthesized from meat proteins using enzymes. ACE or angiotensin-converting enzyme is found in many tissues and body fluids in the human body, and it regulates the blood pressure and maintains the electrolyte balance by converting inactive angiotensin I into vasoconstricting angiotensin II, thereby increasing the blood pressure of the body (Meisel et al. 2006). Thus, ACE-inhibitory peptides have been found to block this conversion of angiotensin I to angiotensin II and help maintain blood pressure (Ogbru and Marks 2008). Although several drugs that inhibit this conversion are present in the market, the need to find natural solutions to this problem of hypertension gave birth to the research of ACE-inhibitory peptides. Due to their smaller size, these peptides can easily cross the digestive epithelial barrier and reach the blood vessels, thereby providing a natural cure (Yust et al. 2003). Currently, ACE peptides have largely been isolated from whey proteins, fish, pork, chicken meat, chicken eggs, and beef (Ghassem et al. 2011; Jang and Lee 2005; Saiga et al. 2003; Vercruysse et al. 2005). This has mainly been achieved by enzymatic hydrolysis of the meat. Based on the type of meat used, a wide range of enzymes has been used for hydrolysis, such as trypsin, chymotripsin, pepsin, pancreatin, thermolysin, and proteinase A. However, a correct combination of enzymes is advised in order to attain high yields.

\subsection{Concluding Remarks}

Functional foods stand as a new category of foods with numerous health benefits, such as low cholesterol, high antioxidants, and anticancer and antiaging properties, etc. In recent years, demand for such food is increasing, which could be due to consumer awareness of foods and beverages with health-promoting nutrients. Several methods are in practice in the food industry for the processing of these functional foods, such as conventional heat treatment or chemically mediated extraction of nutraceuticals from plant parts. In recent years, numerous novel technologies were employed, such as high hydrostatic pressure, pulsed electric field, ultrasonication, etc.; however, these processing methods have several drawbacks, such as being expensive, tedious to operate, having high processing costs, and requiring stringent process control 
operations. Enzymes are environmentally friendly and nontoxic and do not require expensive technology and operating expertise. Their use offers the potential for many exciting applications in the improvement of foods, and they are commonly used in the production of nutraceuticals and in the synthesis of a range of functional foods. However, there is still a long way to go in recognizing the full potential of enzymes in food and other industrial applications; for example, a range of increasingly sophisticated enzymes for specific functional food applications should be developed. In addition, various properties of enzymes, such as thermostability, specificity, and catalytic efficiency, should be improved to withstand extreme conditions, such as such as high temperature, $\mathrm{pH}$, etc., for several industrial processes.

\section{REFERENCES}

Afifi, A. F., Abo-Elmagd, H. I., \& Housseiny, M. M. 2014. Improvement of alkaline protease production by Penicillium chrysogenum NRRL 792 through physical and chemical mutation, optimization, characterization and genetic variation between mutant and wild-type strains. Annals of Microbiology, 64(2), 521-530.

Alemany-Costa, L., González-Larena, M., García-Llatas, G., Alegría, A., Barberá, R., Sánchez-Siles, L. M., \& Lagarda, M. J. 2012. Sterol stability in functional fruit beverages enriched with different plant sterol sources. Food Research International, 48(1), 265-270.

Alissa, E. M., \& Ferns, G. A. 2012. Functional foods and nutraceuticals in the primary prevention of cardiovascular diseases. Journal of Nutrition and Metabolism, 2012, 569486.

Alissa, E. M., \& Ferns, G. A. 2014. Potential cardio-protective effects of functional foods. In: Noomhorm, A., Ahmad I. and Anal A. K. (Eds). Functional Foods and Dietary Supplements: Processing Effects and Health Benefits, pp. 463-487. John Wiley \& Sons, Chichester, UK.

Annunziata, A., \& Vecchio, R. 2011. Functional foods development in the European market: A consumer perspective. Journal of Functional Foods, 3(3), 223-228.

Arihara, K. 2006. Strategies for designing novel functional meat products. Meat Science, 74(1), 219-229.

Basu, A., Nguyen, A., Betts, N. M., \& Lyons, T. J. 2014. Strawberry as a functional food: An evidence-based review. Critical Reviews in Food Science and Nutrition, 54(6), 790-806.

Berger, A., Jones, P., \& Abumweis, S. S. 2004. Plant sterols: Factors affecting their efficacy and safety as functional food ingredients. Lipids in Health and Disease, 3(5), 907-919.

Brennan, C. S., \& Cleary, L. J. 2005 . The potential use of cereal $(1 \rightarrow 3,1 \rightarrow 4)-\beta$-D-glucans as functional food ingredients. Journal of Cereal Science, 42(1), 1-13.

Briones-Labarca, V., Plaza-Morales, M., Giovagnoli-Vicuña, C., \& Jamett, F. 2015. High hydrostatic pressure and ultrasound extractions of antioxidant compounds, sulforaphane and fatty acids from Chilean papaya (Vasconcellea pubescens) seeds: Effects of extraction conditions and methods. LWT-Food Science and Technology, 60(1), 525-534.

Brouwer, I. A., Katan, M. B., \& Zock, P. L. 2004. Dietary $\alpha$-linolenic acid is associated with reduced risk of fatal coronary heart disease, but increased prostate cancer risk: A meta-analysis. The Journal of Nutrition, 134(4), 919-922.

Canene-Adams, K., Campbell, J. K., Zaripheh, S., Jeffery, E. H., \& Erdman, J. W. 2005. The tomato as a functional food. The Journal of Nutrition, 135(5), 1226-1230.

Cartea, M. E., \& Velasco, P. 2008. Glucosinolates in Brassica foods: Bioavailability in food and significance for human health. Phytochemistry Reviews, 7(2), 213-229.

Charalampopoulos, D., Wang, R., Pandiella, S., \& Webb, C. 2002. Application of cereals and cereal components in functional foods: A review. International Journal of Food Microbiology, 79(1), 131-141.

Cortés-Olmos, C., Leiva-Brondo, M., Roselló, J., Raigón, M. D., \& Cebolla-Cornejo, J. 2014. The role of traditional varieties of tomato as sources of functional compounds. Journal of the Science of Food and Agriculture, 94(14), 2888-2904.

Davies, G., \& Henrissat, B. 1995. Structures and mechanisms of glycosyl hydrolases. Structure, 3(9), 853-859.

Dawson-Hughes, B., Harris, S. S., Krall, E. A., \& Dallal, G. E. 1997. Effect of calcium and vitamin D supplementation on bone density in men and women 65 years of age or older. New England Journal of Medicine, 337(10), 670-676.

Decker, E. A., \& Park, Y. 2010. Healthier meat products as functional foods. Meat Science, 86(1), 49-55. 
Delzenne, N. M., \& Roberfroid, M. 1994. Physiological effects of non-digestible oligosaccharides. LWT-Food Science and Technology, 27(1), 1-6.

De Marzo, A. M., Platz, E. A., Sutcliffe, S., Xu, J., Grönberg, H., Drake, C. G., \& Nelson, W. G. 2007. Inflammation in prostate carcinogenesis. Nature Reviews Cancer, 7(4), 256-269.

De Wals, P., Tairou, F., Van Allen, M. I., Uh, S.-H., Lowry, R. B., Sibbald, B., \& Crowley, M. 2007. Reduction in neural-tube defects after folic acid fortification in Canada. New England Journal of Medicine, 357(2), $135-142$.

Diplock, A., Charuleux, J.-L., Crozier-Willi, G., Kok, F., Rice-Evans, C., Roberfroid, M., \& Vina-Ribes, J. 1998. Functional food science and defence against reactive oxidative species. British Journal of Nutrition, $80(\mathrm{~S} 1), \mathrm{S} 77-\mathrm{S} 112$.

Diplock, A. T., Aggett, P. J., Ashwell, M., Bornet, F., Fern, E. B., \& Roberfroid, M. B. 1999. Scientific concepts in functional foods in Europe: Consensus document. British Journal of Nutrition (United Kingdom), 81, S1-S27.

Drago, L., Toscano, M., \& Pigatto, P. 2013. Probiotics: Immunomodulatory properties in allergy and eczema. Giornale italiano di dermatologia e venereologia: Organo ufficiale, Societa italiana di dermatologia e sifilografia, 148(5), 505-514.

El Sohaimy, S. 2012. Functional foods and nutraceuticals-modern approach to food science. World Applied Sciences Journal, 20(5), 691-708.

FAO. 2001. General specifications and considerations for enzyme preparations used in food processing. 57th session. Compendium of Food Additive Specifications. FAO Food and Nutrition Paper, 52.

Fernández-Ginés, J. M., Fernández-López, J., Sayas-Barberá, E., \& Pérez-Alvarez, J. 2005. Meat products as functional foods: A review. Journal of Food Science, 70(2), R37-R43.

Ferrari, C. K. 2007. Functional foods and physical activities in health promotion of aging people. Maturitas, 58(4), 327-339.

Gänzle, M. G. 2012. Enzymatic synthesis of galacto-oligosaccharides and other lactose derivatives (heterooligosaccharides) from lactose. International Dairy Journal, 22(2), 116-122.

Gattuso, G., Barreca, D., Gargiulli, C., Leuzzi, U., \& Caristi, C. 2007. Flavonoid composition of citrus juices. Molecules, 12(8), 1641-1673.

Ghassem, M., Arihara, K., Babji, A. S., Said, M., \& Ibrahim, S. 2011. Purification and identification of ACE inhibitory peptides from Haruan (Channa striatus) myofibrillar protein hydrolysate using HPLC-ESITOF MS/MS. Food Chemistry, 129(4), 1770-1777.

Gibson, G. R. \& Roberfroid, M. B. 1995. Dietary modulation of the human colonic microbiota introducing the concept of prebiotics. Journal of Nutrition 125(6), 1401-1412.

Goldin, B. R. 1998. Health benefits of probiotics. The British Journal of Nutrition, 80(4), S203-S207.

Granato, D., Branco, G. F., Cruz, A. G., Faria, J. D. A. F., \& Shah, N. P. 2010. Probiotic dairy products as functional foods. Comprehensive Reviews in Food Science and Food Safety, 9(5), 455-470.

Gu, J., Ahn-Jarvis, J. H., Riedl, K. M., Schwartz, S. J., Clinton, S. K., \& Vodovotz, Y. 2013. Characterization of black raspberry functional food products for cancer prevention human clinical trials. Journal of Agricultural and Food Chemistry 62(18), 3997-4006.

Guo, Z., \& Xu, X. 2005. New opportunity for enzymatic modification of fats and oils with industrial potentials Organic \& Biomolecular Chemistry, 3(14), 2615-2619.

Halsted, C. H. 2003. Dietary supplements and functional foods: 2 sides of a coin? The American Journal of Clinical Nutrition, 77(4), 1001S-1007S.

Hartmann, R., \& Meisel, H. 2007. Food-derived peptides with biological activity: From research to food applications. Current Opinion in Biotechnology, 18(2), 163-169.

Hasler, C. M. 1998. Functional foods: Their role in disease prevention and health promotion. Food TechnologyChampaign then Chicago, 52, 63-147.

Hasler, C. M. 2000. The changing face of functional foods. Journal of the American College of Nutrition, 19(Suppl. 5), 499S-506S.

Hasler, C. M. 2002. Functional foods: Benefits, concerns and challenges-A position paper from the American Council on Science and Health. The Journal of Nutrition, 132(12), 3772-3781.

Hasler, C. M., \& Brown, A. C. 2009. Position of the American Dietetic Association: Functional foods. Journal of the American Dietetic Association, 109(4), 735-746.

Henry, C. 2010. Functional foods. European Journal of Clinical Nutrition, 64(7), 657-659. 
Holub, D. J., \& Holub, B. J. 2004. Omega-3 fatty acids from fish oils and cardiovascular disease. Molecular and Cellular Biochemistry, 263(1), 217-225.

Ishida, H., Suzuno, H., Sugiyama, N., Innami, S., Tadokoro, T., \& Maekawa, A. 2000. Nutritive evaluation on chemical components of leaves, stalks and stems of sweet potatoes (Ipomoea batatas poir). Food Chemistry, 68(3), 359-367.

Jaiswal, A. K., Rajauria, G., Abu-Ghannam, N., \& Gupta, S. 2011. Phenolic composition, antioxidant capacity and antibacterial activity of selected Irish Brassica vegetables. Natural Products Communications, 6(9), 1299-1304.

Jang, A., \& Lee, M. 2005. Purification and identification of angiotensin converting enzyme inhibitory peptides from beef hydrolysates. Meat Science, 69(4), 653-661.

Jeffery, E., Brown, A., Kurilich, A., Keck, A., Matusheski, N., Klein, B., \& Juvik, J. 2003. Variation in content of bioactive components in broccoli. Journal of Food Composition and Analysis, 16(3), 323-330.

Jiménez-Colmenero, F., Carballo, J., \& Cofrades, S. 2001. Healthier meat and meat products: Their role as functional foods. Meat Science, 59(1), 5-13.

Johanningsmeier, S. D., \& Harris, G. K. 2011. Pomegranate as a functional food and nutraceutical source. Annual Review of Food Science and Technology, 2, 181-201.

Kadam, S., \& Prabhasankar, P. 2010. Marine foods as functional ingredients in bakery and pasta products. Food Research International, 43(8), 1975-1980.

Kamal-Eldin, A., Moazzami, A., \& Washi, S. 2011. Sesame seed lignans: Potent physiological modulators and possible ingredients in functional foods and nutraceuticals. Recent Patents on Food, Nutrition \& Agriculture, 3(1), 17-29.

Kim, C. H., Park, M. K., Kim, S. K., \& Cho, Y. H. 2014. Antioxidant capacity and anti-inflammatory activity of lycopene in watermelon. International Journal of Food Science \& Technology, 49(9), 2083-2091.

Koch, A., Brandenburger, S., Türpe, S., \& Birringer, M. 2014. The need for a legal distinction of nutraceuticals. Food and Nutrition Sciences, 5, 905-913.

Korhonen, H., \& Pihlanto, A. 2003. Food-derived bioactive peptides-Opportunities for designing future foods. Current Pharmaceutical Design, 9(16), 1297-1308.

Kralik, G., Kušec, G., Grčević, M., Đurkin, I., \& Kralik, I. 2012. Animal products as coventional and functional food-An overwiev. Acta Agriculturae Slovenica, 3, 18.

Lafarga, T., \& Hayes, M. 2014. Bioactive peptides from meat muscle and by-products: Generation, functionality and application as functional ingredients. Meat Science, 98(2), 227-239.

Landry, T. D., Chew, L., Davis, J. W., Frawley, N., Foley, H. H., Stelman, S. J., \& Hanselman, D. S. 2003. Safety evaluation of an $\alpha$-amylase enzyme preparation derived from the archaeal order Thermococcales as expressed in Pseudomonas fluorescens biovar I. Regulatory Toxicology and Pharmacology, 37(1), $149-168$.

Lasekan, O. 2014. Exotic berries as a functional food. Current Opinion in Clinical Nutrition \& Metabolic Care, 17(6), 589-595.

Lavecchia, T., Rea, G., Antonacci, A., \& Giardi, M. T. 2013. Healthy and adverse effects of plant-derived functional metabolites: The need of revealing their content and bioactivity in a complex food matrix. Critical Reviews in Food Science and Nutrition, 53(2), 198-213.

Lima, I., Guraya, H., \& Champagne, E. 2002. The functional effectiveness of reprocessed rice bran as an ingredient in bakery products. Food/Nahrung, 46(2), 112-117.

Liu, R. H. 2003. Health benefits of fruit and vegetables are from additive and synergistic combinations of phytochemicals. The American Journal of Clinical Nutrition, 78(3), 517S-520S.

Liu, Z., Liu, L., Österlund, T., Hou, J., Huang, M., Fagerberg, L., \& Nielsen, J. 2014. Improved production of a heterologous amylase in saccharomyces cerevisiae by inverse metabolic engineering. Applied and Environmental Microbiology, 80(17), 5542-5550.

Manning, T. S., \& Gibson, G. R. 2004. Prebiotics. Best Practice \& Research Clinical Gastroenterology, 18(2), 287-298.

Mantovani, M. S., Bellini, M. F., Angeli, J. P. F., Oliveira, R. J., Silva, A. F., \& Ribeiro, L. R. 2008. $\beta$-Glucans in promoting health: Prevention against mutation and cancer. Mutation Research/Reviews in Mutation Research, 658(3), 154-161.

Meisel, H., Walsh, D., Murray, B., \& FitzGerald, R. 2006. ACE inhibitory peptides. In: Mine, Y. and Shahidi, F. (Eds.). Nutraceutical Proteins and Peptides in Health and Disease, pp. 269-315. CRC Press, Boca Raton, FL. 
Menrad, K. 2003. Market and marketing of functional food in Europe. Journal of Food Engineering, 56(2), $181-188$.

Meyer, A. S. 2010. Enzyme technology for precision functional food ingredient processes. Annals of the New York Academy of Sciences, 1190(1), 126-132.

Milner, J. 1999. Functional foods and health promotion. The Journal of Nutrition, 129(7), 1395S-1397S.

Mohamed, S. 2014. Functional foods against metabolic syndrome (obesity, diabetes, hypertension and dyslipidemia) and cardiovasular disease. Trends in Food Science \& Technology, 35(2), 114-128.

Muguerza, E., Gimeno, O., Ansorena, D., Bloukas, J., \& Astiasarán, I. 2001. Effect of replacing pork back fat with pre-emulsified olive oil on lipid fraction and sensory quality of Chorizo de Pamplona-A traditional Spanish fermented sausage. Meat Science, 59(3), 251-258.

Mussatto, S. I., \& Mancilha, I. M. 2007. Non-digestible oligosaccharides: A review. Carbohydrate Polymers, 68(3), 587-597.

Nagpal, R., Kumar, A., Kumar, M., Behare, P. V., Jain, S., \& Yadav, H. 2012. Probiotics, their health benefits and applications for developing healthier foods: A review. FEMS Microbiology Letters, 334(1), $1-15$.

Navarro-González, I., García-Valverde, V., García-Alonso, J., \& Periago, M. 2011. Chemical profile, functional and antioxidant properties of tomato peel fiber. Food Research International, 44(5), 1528-1535.

Ogbru, O. 2008. ACE Inhibitors (Angiotensin Converting Enzyme Inhibitors). In: Marks, J. (Ed.). Medical and Pharmacy. MedicineNet, Inc. Available at http://www.medicinenet.com/ace_inhibitors/article.htm.

Patterson, J., \& Burkholder, K. 2003. Application of prebiotics and probiotics in poultry production. Poultry Science, 82(4), 627-631.

Pérez-Alvarez, J. A. 2008. Overview of meat products as functional foods. In: J. F. López (Ed.). Technological Strategies for Functional Meat Products Development, pp. 1-17. Transworld Research Network, Kerela, India.

Pharmaceutiques, U. D. L. 1995. Dietary modulation of the human colonie microbiota: Introducing the concept of prebiotics. The Journal of Nutrition, 125, 1401-1412.

Puri, M., Sharma, D., \& Barrow, C. J. 2012. Enzyme-assisted extraction of bioactives from plants. Trends in Biotechnology, 30(1), 37-44.

Rastall, R. A. 2013. Gluco and galacto-oligosaccharides in food: Update on health effects and relevance in healthy nutrition. Current Opinion in Clinical Nutrition \& Metabolic Care, 16(6), 675-678.

Reddy, B. S., Hirose, Y., Cohen, L. A., Simi, B., Cooma, I., \& Rao, C. V. 2000. Preventive potential of wheat bran fractions against experimental colon carcinogenesis: Implications for human colon cancer prevention. Cancer Research, 60(17), 4792-4797.

Reglero, G., Frial, P., Cifuentes, A., García-Risco, M. R., Jaime, L., Marin, F. R., Palanca, V., Ruiz-Rodríguez, A., Santoyo, S., Señoráns, F. J., Soler-Rivas, C., Torres, C., and Ibañez, E. 2008. Meat-based functional foods for dietary equilibrium omega-6/omega-3. Molecular Nutrition \& Food Research, 52(10), $1153-1161$.

Rice-Evans, C. 2001. Flavonoid antioxidants. Current Medicinal Chemistry, 8(7), 797-807.

Robbins, R. J., Keck, A.-S., Banuelos, G., \& Finley, J. W. 2005. Cultivation conditions and selenium fertilization alter the phenolic profile, glucosinolate, and sulforaphane content of broccoli. Journal of Medicinal Food, 8(2), 204-214.

Roberfroid, M. 1997. Health benefits of non-digestible oligosaccharides. In: Kritchevsky, D. \& Bonfield, C. (Eds.). Dietary Fiber in Health and Disease, pp. 211-219. Plenum Press, New York, USA.

Roberfroid, M. B. 2000. Prebiotics and probiotics: Are they functional foods? The American Journal of Clinical Nutrition, 71(6), 1682s-1687s.

Roberfroid, M. 2007. Prebiotics: The concept revisited. The Journal of Nutrition, 137(3), 830S-837S.

Saiga, A., Okumura, T., Makihara, T., Katsuta, S., Shimizu, T., Yamada, R., \& Nishimura, T. 2003. Angiotensin I-converting enzyme inhibitory peptides in a hydrolyzed chicken breast muscle extract. Journal of Agricultural and Food Chemistry, 51(6), 1741-1745.

San Martin, M., Barbosa-Cánovas, G., \& Swanson, B. 2002. Food processing by high hydrostatic pressure. Critical Reviews in Food Science and Nutrition, 42(6), 627-645.

Saxelin, M. 2008. Probiotic formulations and applications, the current probiotics market, and changes in the marketplace: A European perspective. Clinical Infectious Diseases, 46(Suppl. 2), S76-S79.

Schieber, A., Stintzing, F., \& Carle, R. 2001. By-products of plant food processing as a source of functional compounds-Recent developments. Trends in Food Science \& Technology, 12(11), 401-413. 
Schrezenmeir, J., \& de Vrese, M. 2001. Probiotics, prebiotics, and synbiotics_Approaching a definition. The American Journal of Clinical Nutrition, 73(2), 361s-364s.

Segovia, F. J., Luengo, E., Corral-Pérez, J. J., Raso, J., \& Almajano, M. P. 2015. Improvements in the aqueous extraction of polyphenols from borage (Borago officinalis L.) leaves by pulsed electric fields: Pulsed electric fields (PEF) applications. Industrial Crops and Products. doi:10.1016/j.indcrop.2014.11.010.

Shahidi, F. 2009. Nutraceuticals and functional foods: Whole versus processed foods. Trends in Food Science \& Technology, 20(9), 376-387.

Siro, I., Kapolna, E., Kapolna, B., \& Lugasi, A. 2008. Functional food. Product development, marketing and consumer acceptance-A review. Appetite, 51(3), 456-467.

Stacewicz-Sapuntzakis, M., Bowen, P. E., Hussain, E. A., Damayanti-Wood, B. I., \& Farnsworth, N. R. 2001. Chemical composition and potential health effects of prunes: A functional food? Critical Reviews in Food Science and Nutrition, 41(4), 251-286.

Stewart, A. J., Bozonnet, S., Mullen, W., Jenkins, G. I., Lean, M. E., \& Crozier, A. 2000. Occurrence of flavonols in tomatoes and tomato-based products. Journal of Agricultural and Food Chemistry, 48(7), 2663-2669.

Swennen, K., Courtin, C. M., \& Delcour, J. A. 2006. Non-digestible oligosaccharides with prebiotic properties. Critical Reviews in Food Science and Nutrition, 46(6), 459-471.

Torres, D. P., Gonçalves, M. D. P. F., Teixeira, J. A., \& Rodrigues, L. R. 2010. Galacto-oligosaccharides: Production, properties, applications, and significance as prebiotics. Comprehensive Reviews in Food Science and Food Safety, 9(5), 438-454.

Van Den Broek, L. A., \& Voragen, A. G. 2008. Bifidobacterium-glycoside hydrolases and (potential) prebiotics. Innovative Food Science \& Emerging Technologies, 9(4), 401-407.

Van den Broek, L. A., Hinz, S. W., Beldman, G., Doeswijk-Voragen, C. H., Vincken, J.-P., \& Voragen, A. G. 2005. Glycosyl hydrolases from Bifidobacterium adolescentis DSM20083. An overview. Le Lait, 85(12), 125-133.

Vercruysse, L., Van Camp, J., \& Smagghe, G. 2005. ACE inhibitory peptides derived from enzymatic hydrolysates of animal muscle protein: A review. Journal of Agricultural and Food Chemistry, 53(21), 8106-8115.

Viñas, P., Bravo-Bravo, M., López-García, I., \& Hernández-Córdoba, M. 2013. Quantification of $\beta$-carotene, retinol, retinyl acetate and retinyl palmitate in enriched fruit juices using dispersive liquid-liquid microextraction coupled to liquid chromatography with fluorescence detection and atmospheric pressure chemical ionization-mass spectrometry. Journal of Chromatography A, 1275, 1-8.

Vitaglione, P., Napolitano, A., \& Fogliano, V. 2008. Cereal dietary fibre: A natural functional ingredient to deliver phenolic compounds into the gut. Trends in Food Science \& Technology, 19(9), 451-463.

Wang, S., DeGroff, V. L., \& Clinton, S. K. 2003. Tomato and soy polyphenols reduce insulin-like growth factor-I-stimulated rat prostate cancer cell proliferation and apoptotic resistance in vitro via inhibition of intracellular signaling pathways involving tyrosine kinase. The Journal of Nutrition, 133(7), 2367-2376.

Weidner, C., Krempf, M., Bard, J.-M., Cazaubiel, M., \& Bell, D. 2008. Cholesterol lowering effect of a soy drink enriched with plant sterols in a French population with moderate hypercholesterolemia. Lipids in Health and Disease, 7(1), 35-42.

Whitehead, J. 2008. 12 Functional drinks containing herbal extracts. In: Ashurst, P. R. (Ed.). Chemistry and Technology of Soft Drinks and Fruit Juices, pp. 300-335. John Wiley \& Sons, Oxford, UK.

Wood, P. J. 2007. Cereal $\beta$-glucans in diet and health. Journal of Cereal Science, 46(3), 230-238.

Wu, G., Collins, J. K., Perkins-Veazie, P., Siddiq, M., Dolan, K. D., Kelly, K. A., Meininger, C. J. 2007. Dietary supplementation with watermelon pomace juice enhances arginine availability and ameliorates the metabolic syndrome in Zucker diabetic fatty rats. The Journal of Nutrition, 137(12), 2680-2685.

Yamaguishi, C. T., Spier, M. R., Lindner, J. D. D., Soccol, V. T., \& Soccol, C. R. 2011. Current market trends and future directions. In: Liong, M. T. (Ed.), v, pp. 299-319. Springer-Verlag, Berlin.

Yep, Y. L., Li, D., Mann, N. J., Bode, O., \& Sinclair, A. J. 2002. Bread enriched with microencapsulated tuna oil increases plasma docosahexaenoic acid and total omega-3 fatty acids in humans. Asia Pacific Journal of Clinical Nutrition, 11(4), 285-291.

Yust, M. A. M., Pedroche, J., Giron-Calle, J., Alaiz, M., Millán, F., \& Vioque, J. 2003. Production of ace inhibitory peptides by digestion of chickpea legumin with alcalase. Food Chemistry, 81(3), 363-369.

Zhang, W., Xiao, S., Samaraweera, H., Lee, E. J., \& Ahn, D. U. 2010. Improving functional value of meat products. Meat Science, 86(1), 15-31. 